\title{
More lab in the library
}

\author{
Jennifer Rohn, editor of the webzine LabLit.com, asks why so many novels with scientists as \\ central characters have been published this year.
}

For novels set in the world of science, 2010 looks to be a bumper year. Best-selling author Ian McEwan probes the pressures on a climatologist in Solar (Jonathan Cape), while Rajendra Pachauri, head of the Intergovernmental Panel on Climate Change, indulges in a semi-biographical romp in Return To Almora (Rupa). Distinguished American entomologist E. O. Wilson explores the workings of insect and human societies in his debut novel, Anthill (W. W. Norton). And Michael Byers will offer a fictionalized account of the discovery of Pluto in Percival's Planet (Henry Holt), later this summer.

Is this increased attention to science in fiction a recent phenomenon and, if so, what is driving it? Across the tens of thousands of novels published each year, it is difficult to measure how often science crops up as a theme. A subgenre is easier to track, namely 'lab lit'. I coined the term in 2001 to describe realistic novels that contain scientists as central characters plying their trade (see Nature 439, 269; 2006). It is distinct from science fiction, in which the action takes place in speculative worlds and may not involve scientist characters.

After years of personal research, along with reader nominations at my website LabLit.com, I have identified 118 lab-lit novels published by traditional imprints since 1900, and two selfpublished novels that attracted mainstream press attention. Compared with crime fiction, which generates about 600 new books per year in the United Kingdom alone, lab lit is still rare. My list, although not comprehensive and biased towards English-language publications, nevertheless represents a good starting point for trend seeking.

The number of lab-lit books has risen dramatically in the past two decades (see 'Fiction starring scientists'). A few were published sporadically over the past century - such as Sinclair Lewis's Arrowsmith (P. F. Collier, 1925), C. P. Snow's The Search (Gollancz, 1934) and William Cooper's The Struggles of Albert Woods (Doubleday, 1953). But since the late 1980s, there has been a surge in activity, reaching some $5-10$ books per year. The timing of this upturn would explain why, after reading my first lab-lit novel in graduate school in the early 1990s - Cantor's Dilemma (Penguin, 1991) by

\section{FICTION STARRING SCIENTISTS}

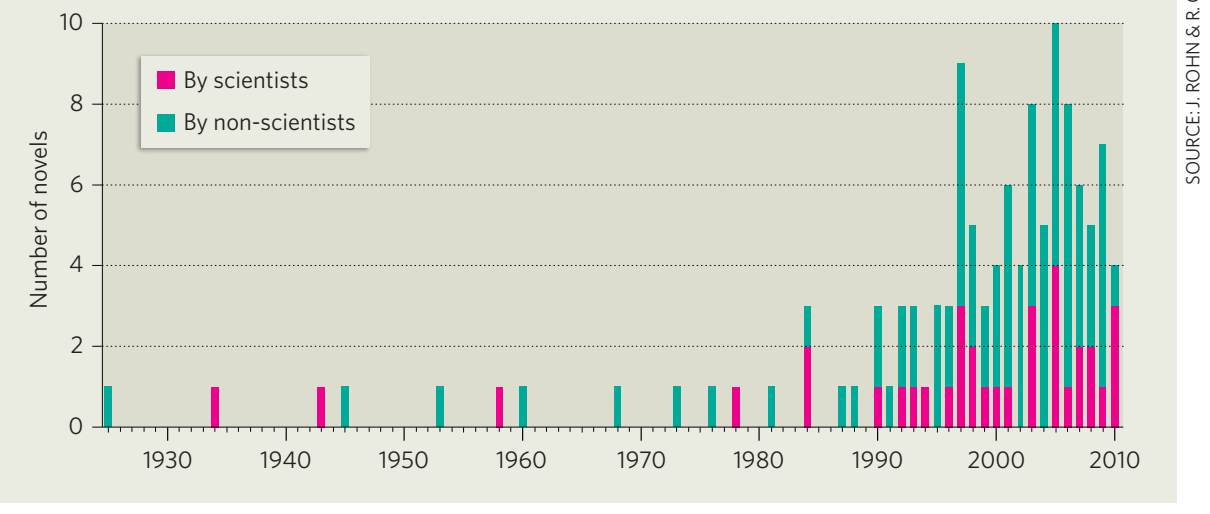

Carl Djerassi - I couldn't find anything else like it in the bookshops. I didn't know it then, but I was witnessing the end of a protracted literary drought.

Who is writing these novels? In my data set, I categorized authors as trained 'scientists' if they had completed a doctorate in science or mathematics, even if they hadn't stayed in the profession. Both before and after the 1980s upturn, just under half of the books were written by scientists. This high fraction and its persistence surprised me, as did the fact that the recent growth in lab-lit novels could not be attributed to either of the authorship camps.

The diversity of lab-lit books suggests that the novels are grounded in curiosity rather than in scientific topicality. A range of settings - from fisheries and meteorology to moth development, black holes and artificial intelligence - underpins human stories that trace classic themes of love, loss, redemption, comedy and tragedy. Many books focus on historical fiction about real-life scientists (especially Albert Einstein, Charles Darwin and Marie Curie) or significant scientific sites, such as Los Alamos National Laboratory in New Mexico; Bletchley Park, UK; or Darwin's ship HMS Beagle. Even taking into account the long gestation period, there was no flurry of books responding to the recombinant DNA revolution in the 1980s, for example, or the launch of the Human Genome Project in 1990.

So why the lab-lit surge? Rather than technology as science fiction does, lab lit tends to focus on the intricacies of scientific work and scientists as people. Writers might be responding to social trends that have made science and technology more palatable, encouraged by a 'geek chic' movement and the attention devoted to sci-art collaborations. Or, a critical mass of well-known authors penning lab lit might have inspired others to try. Around the time of the upturn, established literary figures such as William Boyd, Neal Stephenson, Richard Powers, Jonathan Lethem and Simon Mawer published novels about scientists for the first time, which may have influenced other authors and publishers.

Recent best-sellers might have signalled to publishers that lab lit is an area ripe for financial exploitation. Readers who are increasingly interested in science create more demand, thereby feeding a virtuous publishing cycle. The rise of electronic publishing and online communities may further fuel the growth in lab-lit fiction by bringing the genre to the attention of more readers and allowing potential writers to bypass traditional publishers.

We don't know if the trend will continue, but if these factors continue to raise the profile of lab-based literature, then supply will surely follow. Unscientifically, I'm keeping my fingers crossed.

Jennifer Rohn is a cell biologist at University College London, London WC1E 6BT, UK. Her second novel, The Honest Look, will be published later this year.

e-mail: jenny@lablit.com reflecting society's hopes and fears about 